\title{
Effects of Solution Treatment on the Microstructure, Tensile Properties, and Impact Toughness of an Al-5.0Mg-3.0Zn-1.0Cu Cast Alloy
}

\author{
Hua-Ping Tang ${ }^{1} \cdot$ Qu-Dong Wang ${ }^{1} \cdot$ Colin Luo $^{2}$. Chuan Lei ${ }^{1} \cdot$ Tian-Wen Liu ${ }^{1} \cdot$ Zhong-Yang Li $^{1} \cdot$ Kui Wang $^{1}$. \\ Hai-Yan Jiang ${ }^{1} \cdot$ Wen-Jiang Ding ${ }^{1}$
}

Received: 25 December 2019 / Revised: 9 April 2020 / Published online: 8 June 2020

(C) The Chinese Society for Metals (CSM) and Springer-Verlag GmbH Germany, part of Springer Nature 2020

\begin{abstract}
This study investigates the effect of solution treatment (at $470{ }^{\circ} \mathrm{C}$ for $0-48 \mathrm{~h}$ ) on the microstructural evolution, tensile properties, and impact properties of an $\mathrm{Al}-5.0 \mathrm{Mg}-3.0 \mathrm{Zn}-1.0 \mathrm{Cu}(\mathrm{wt} \%)$ alloy prepared by permanent gravity casting. The results show that the as-cast microstructure consists of $\alpha$-Al dendrites and a network-like pattern of $\mathrm{T}-\mathrm{Mg}_{32}(\mathrm{AlZnCu})_{49}$ phases. Most of the T-phases were dissolved within $24 \mathrm{~h}$ at $470{ }^{\circ} \mathrm{C}$; and a further prolonging of solution time resulted in a rapid growth of $\alpha$ - $\mathrm{Al}$ grains. No transformation from the T-phase to the $\mathrm{S}-\mathrm{Al}_{2} \mathrm{CuMg}$ phase was discovered in this alloy. Both the tensile properties and impact toughness increased quickly, reached a maximum peak value, and decreased gradually as the solution treatment proceeded. The impact toughness is more closely related to the elongation, and the relationship between impact toughness and elongation appears to obey an equation: $\mathrm{IT}=8.43 \mathrm{EL}-3.46$. After optimal solution treatment at $470{ }^{\circ} \mathrm{C}$ for $24 \mathrm{~h}$, this alloy exhibits excellent mechanical properties with the ultimate tensile strength, yield strength, elongation and impact toughness being 431.6 MPa, 270.1 MPa, $19.4 \%$ and $154.7 \mathrm{~kJ} / \mathrm{m}^{2}$, which are comparable to that of a wrought $\mathrm{Al}-$ $6.0 \mathrm{Mg}-0.7 \mathrm{Mn}$ alloy (5E06, a 5xx aluminum alloy). Due to its excellent comprehensive combination of mechanical properties, this cast alloy has high potential for use in components which require medium strength, high ductility and high toughness.
\end{abstract}

Keywords $\mathrm{Al}-\mathrm{Mg}-\mathrm{Zn}-\mathrm{Cu}$ cast alloys $\cdot \mathrm{T}-\mathrm{Mg}_{32}(\mathrm{AlZn})_{49}$ phase $\cdot \mathrm{S}-\mathrm{Al}_{2} \mathrm{CuMg}$ phase $\cdot$ Impact toughness $\cdot$ Mechanical properties

\section{Introduction}

Cast aluminum alloys are widely used in the automotive field due to their low density, high specific strength and high corrosive resistance. Recent developments in lightweight automotive materials have contributed greatly to the research and development of high strength cast aluminum alloys like as $\mathrm{Al}-\mathrm{Cu}-\mathrm{Mn}[1]$ and $\mathrm{Al}-\mathrm{Mg}-\mathrm{Zn}-\mathrm{Cu}$ [2], which have yield strengths reaching $450 \mathrm{MPa}$ while having ductilities of less

Available online at http://link.springer.com/journal/40195

Qu-Dong Wang

wangqudong@sjtu.edu.cn

1 National Engineering Research Center of Light Alloy Net Forming and State Key Laboratory of Metal Matrix Composites, Shanghai Jiao Tong University, Shanghai 200240, China

2 Schulich School of Engineering, University of Calgary, Calgary, AB, Canada than $8 \%$. Automotive components are often subjected to various loading conditions due to complex road conditions or emergencies like collisions; and the increasing demand for safety, however, has required that these cast aluminum alloys possess an ever increasing higher ductility and impact resistance. Impact resistance mainly depends on the toughness, which is relative to yield strength and ductility. A study by Wang et al. [3] has shown that room temperature impact toughness is closely related to ductility for a sand-casted $\mathrm{Mg}-6 \mathrm{Gd}-3 \mathrm{Y}-0.5 \mathrm{Zr}$ alloy. Thus, high ductility is critical to achieve a high toughness overall.

Changes in the microstructure of an alloy are known to greatly influence mechanical properties, including ductility and strength [4]. Cast Al alloys with a single-phase solid solution microstructure are more likely to have excellent ductility. A high ductility requires the alloying elements to have both a large solubility in the Al matrix and a strong solid solution strengthening effect. Based on existing research [5, 6], $\mathrm{Mg}, \mathrm{Zn}$ and $\mathrm{Cu}$ meet these requirements with the solid solution strengthening effect strongest with 
$\mathrm{Mg}$, moderate with $\mathrm{Cu}$ and weakest with $\mathrm{Zn}$. This study will specifically examine the microstructure and mechanical properties of $\mathrm{Al}-5.0 \mathrm{Mg}-3.0 \mathrm{Zn}-1.0 \mathrm{Cu}$ alloys. Previous research has shown that this alloy not only has excellent mechanical properties under peak-aged conditions, but also an amazing ductility of $20 \%$ under solution treated conditions [2]. A higher ductility found in solution treated alloys will provide a higher impact toughness when compared to that of peak-aged alloys. According to a study by Eskin et al. [7] of hot tearing diagrams for $\mathrm{Al}-\mathrm{Mg}-\mathrm{Zn}$ ternary alloys, the $\mathrm{Al}-5.0 \mathrm{Mg}-3.0 \mathrm{Zn}$ alloys have a minimum hot cracking susceptibility of about 30 . Furthermore, the addition of $1 \% \mathrm{Cu}$ was intended to increase strength. It can be speculated that $\mathrm{Al}-5.0 \mathrm{Mg}-3.0 \mathrm{Zn}-1.0 \mathrm{Cu}$ alloys tend to have better castability compared with other $\mathrm{Al}-\mathrm{Mg}-\mathrm{Zn}-\mathrm{Cu}$ alloys. Overall, this composition is possible to obtain a cast aluminum alloy with high ductility and impact toughness.

During the solidification of $\mathrm{Al}-\mathrm{Mg}-\mathrm{Zn}-\mathrm{Cu}$ alloys, many non-equilibrium phases including $\mathrm{T}-\mathrm{Mg}_{32}(\mathrm{AlZnCu})_{49}$ and $\eta-\mathrm{MgZn}_{2}$ phases are formed due to solute segregation [8]. Solution treatment is often adopted to dissolve these nonequilibrium phases $[9,10]$. Previous studies [11-13] have shown that non-equilibrium $\mathrm{T}$ or $\eta$ phases can transform into the $\mathrm{S}-\mathrm{Al}_{2} \mathrm{CuMg}$ phase during solution treatment. Compared with $T$ or $\eta$ phases, the $\mathrm{S}-\mathrm{Al}_{2} \mathrm{CuMg}$ phase is more stable due to its higher dissolution temperature and remains in final microstructure $[14,15]$; however, these residual S- $\mathrm{Al}_{2} \mathrm{CuMg}$ phases are harmful to alloy strength, because their formation consumes alloying elements like $\mathrm{Cu}$ and $\mathrm{Mg}$. The reduction in alloying elements reduces the degree of super-saturation of the alloy and thus weakens the solid solution strengthening effect. Furthermore, the residual $\mathrm{S}-\mathrm{Al}_{2} \mathrm{CuMg}$ phase also reduces ductility by acting as nucleation site for crack propagation. Consequently, the S-phase transformation has attracted a high level of attention. Previous studies have found that this phase transformation is affected by many factors, such as alloy composition [8], solid solution temperature and solution time [13]. Until now the microstructural evolution of the $\mathrm{Al}-5.0 \mathrm{Mg}-3.0 \mathrm{Zn}-1.0 \mathrm{Cu}$ alloy is not investigated and the transformation of $\mathrm{S}$ phase may also occur in this alloy during solution treatment, which will affect its impact toughness.

This study analyzed an $\mathrm{Al}-5.0 \mathrm{Mg}-3.0 \mathrm{Zn}-1.0 \mathrm{Cu}$ alloy prepared by the permanent gravity casting and closely examined how the microstructure influences tensile and impact properties during solution treatment (at $470{ }^{\circ} \mathrm{C}$ for $0-48 \mathrm{~h}$ ) as it changed. Based on the results of tensile and impact tests, the relationship between impact toughness and elongation was established. The effect of $\mathrm{Cu}$ content on $\mathrm{S}-\mathrm{Al}_{2} \mathrm{CuMg}$ phase transformation was also examined in great detail. The results of this study show that this material has enormous potential for applications in automobile components requiring good ductility and high impact toughness.

\section{Materials and Methods}

To prepare the $\mathrm{Al}-5.0 \mathrm{Mg}-3.0 \mathrm{Zn}-1.0 \mathrm{Cu}$ alloys, pure $\mathrm{Al}$ (99.99 wt\%), pure $\mathrm{Zn}(99.8 \mathrm{wt} \%)$, pure $\mathrm{Mg}(99.8 \mathrm{wt} \%)$ and $\mathrm{Al}-50 \mathrm{Cu}(\mathrm{wt} \%)$ master alloys were melted in an iron crucible in an electrical resistance furnace at $730{ }^{\circ} \mathrm{C}$. To reduce the impurity $(\mathrm{Fe})$, the surface of the crucible was coated with a layer of water glass and magnesium oxide. The melted alloys were degassed with 0.2 wt $\% \mathrm{C}_{2} \mathrm{Cl}_{6}$ before being poured into a permanent mold preheated to $200{ }^{\circ} \mathrm{C}$. The schematic diagram of the cast is shown in Fig. 1a. The chemical composition was measured by an inductively coupled plasma optical emission spectrometer and the results are listed in Table 1 . Samples in size of $10 \mathrm{~mm} \times 10 \mathrm{~mm} \times 10 \mathrm{~mm}$ were directly cut from the center part of the cast for solution treatment in the furnace. Samples were solution treated at $470{ }^{\circ} \mathrm{C}$ for time ranging from $15 \mathrm{~min}$ to $48 \mathrm{~h}$ in air followed by water quenching. The comparative samples were subjected to T6 heat treatment, including solution treatment at $470{ }^{\circ} \mathrm{C}$ for $24 \mathrm{~h}$ in air followed by water quenching and subsequent aging treatment at $150{ }^{\circ} \mathrm{C}$ for $24 \mathrm{~h}$.

Differential scanning calorimetry (DSC) tests were employed to optimize solution treatment and detect the existence of the $\mathrm{S}-\mathrm{Al}_{2} \mathrm{CuMg}$ phase. Samples for microstructural observation and tensile tests were cut in the area $5 \mathrm{~mm}$ from the bottom of the cast. The constituent phases were identified by a poly-functional X-ray diffractometer (XRD) with a $\mathrm{Cu} K \alpha$ source operating at $25 \mathrm{kV}, 50 \mathrm{~mA}$ and at a scanning rate of $5 \% \mathrm{~min}$. The metallographic specimens were prepared by standard mechanical polishing, etched to form an anode film with $25 \mathrm{~g} / \mathrm{L}$ hydrofluoric acid solution, and observed by a Zeiss-Axio Observer A1 polarized optical microscope (OM). The polished specimens were observed using a FEI NOVA 230 field-emission scanning electron microscope (SEM) equipped with an AZtec X-Max 80 X-ray energy-dispersive spectroscope (EDS). The area fraction of the residual phases during solution treatment was calculated using 10 SEM images at $500 \times$ magnification for each condition. The grain size was analyzed using Image-Pro Plus software by examining $10 \mathrm{OM}$ images at $50 \times$ magnification. The isothermal section of $\mathrm{Al}-\mathrm{Mg}-\mathrm{Zn}-\mathrm{Cu}$ phase diagram was calculated using Pandat 2019 (a software package for thermodynamics analysis).

Tensile tests were performed at room temperature using a Zwick/Roell Z020 table-top tester at a strain rate of $1.6 \times 10^{-4} \mathrm{~s}^{-1}$ until fracture occurred. The tensile sample was cut into the dimensions as shown in Fig. 1b. An average of three tensile measurements was taken as the true tensile test result for each state. For the impact tests, the alloys were cut into standard Charpy V-notch test 
a

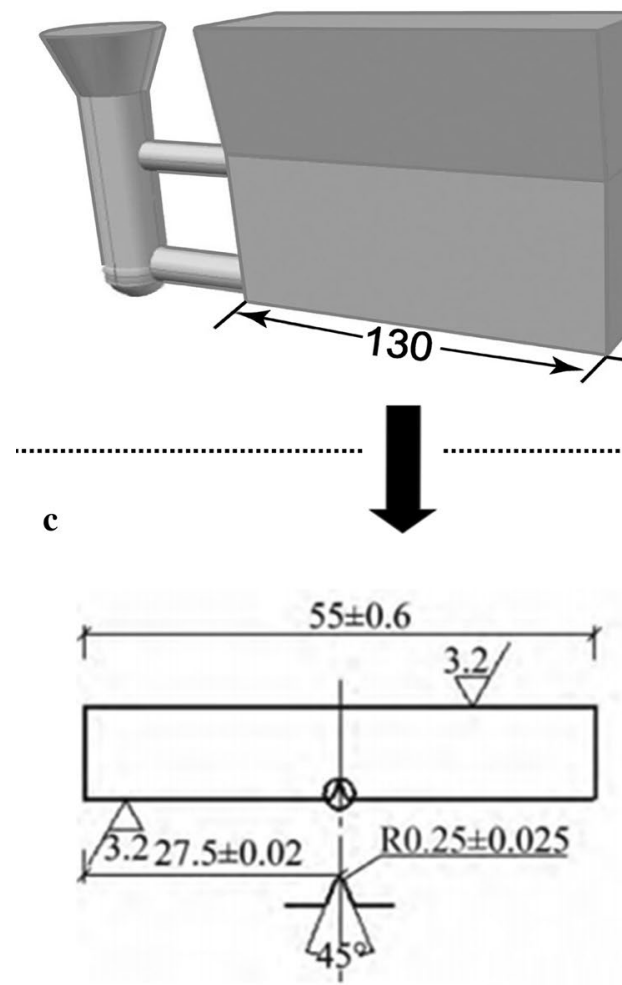

b
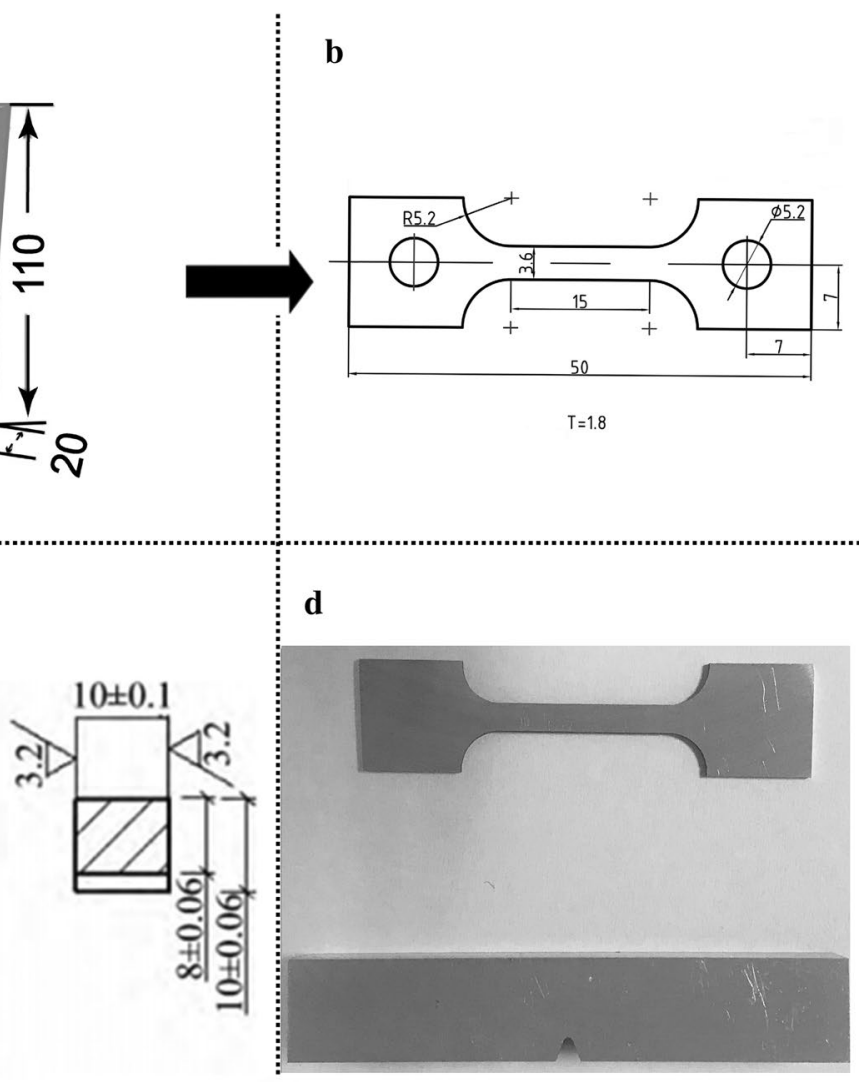

Fig. 1 Schematic diagram of the cast a, dimensions of the tensile specimen $\mathbf{b}$, dimensions of the Charpy V-notch test specimen $\mathbf{c}$ (in mm), corresponding tensile and Charpy V-notch impact test sample d

Table 1 Chemical composition of the studied alloy Al-5.0Mg$3.0 \mathrm{Zn}-1.0 \mathrm{Cu}(\mathrm{wt} \%)$

\begin{tabular}{llllll}
\hline $\mathrm{Zn}$ & $\mathrm{Mg}$ & $\mathrm{Cu}$ & $\mathrm{Fe}$ & $\mathrm{Si}$ & $\mathrm{Al}$ \\
\hline 3.10 & 4.85 & 0.97 & 0.16 & 0.14 & $\mathrm{Bal}$. \\
\hline
\end{tabular}

specimens according to GB/T 18658-2002 guidelines (the dimensions of which are shown in Fig. 1c). Impact tests were performed on as-cast, solution treated, T6-treated samples at room temperature using a PTM2000-300 J impact tester, and an average of three measurements taken were used to evaluate the impact toughness.

\section{Results}

\subsection{Microstructural Evolution During Solution Treatment}

To obtain a proper solution temperature, DSC analysis was conducted with the as-cast sample and the DSC heating curve is shown in Fig. 2. This figure depicts a clear endothermic peak at $484{ }^{\circ} \mathrm{C}$, which indicates the melting of the

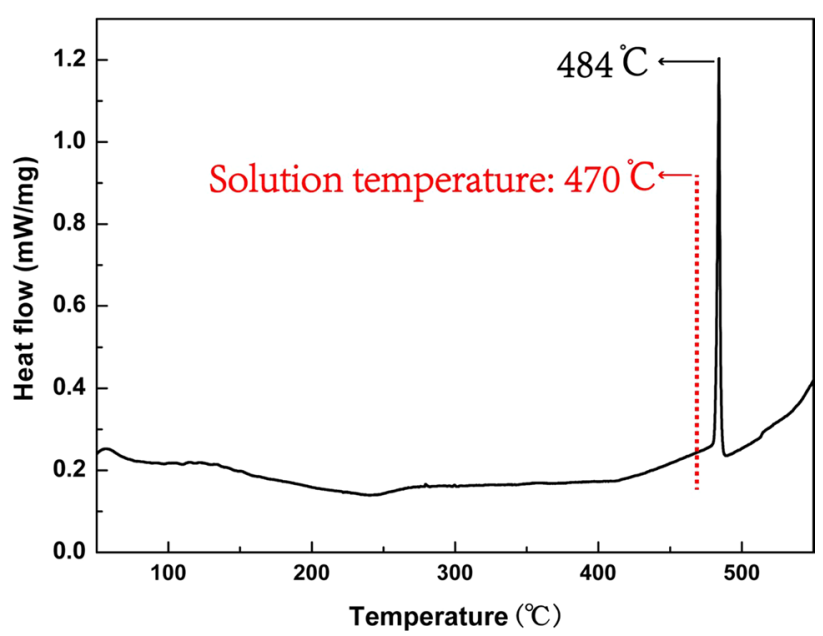

Fig. 2 DSC heating curve of the as-cast $\mathrm{Al}-5.0 \mathrm{Mg}-3.0 \mathrm{Zn}-1.0 \mathrm{Cu}$ alloy

secondary phase in the as-cast $\mathrm{Al}-5.0 \mathrm{Mg}-3.0 \mathrm{Zn}-1.0 \mathrm{Cu}$ alloy. Therefore, careful consideration was made to ensure that the solution treatment temperature did not exceed $484{ }^{\circ} \mathrm{C}$. Considering the initial melting temperature of the 
secondary phase and the accuracy of furnace, $470{ }^{\circ} \mathrm{C}$ was chosen as the solution temperature, as shown in Fig. 2.

Based on the XRD patterns (Fig. 3), the main phases in the as-cast alloy were the $\alpha-\mathrm{Al}$ and $\mathrm{T}-\mathrm{M}_{\mathrm{g} 32}(\mathrm{AlZnCu})_{49}$ phases. When compared to the patterns of the as-cast material (Fig. 3a), the results of solution treated sample differed

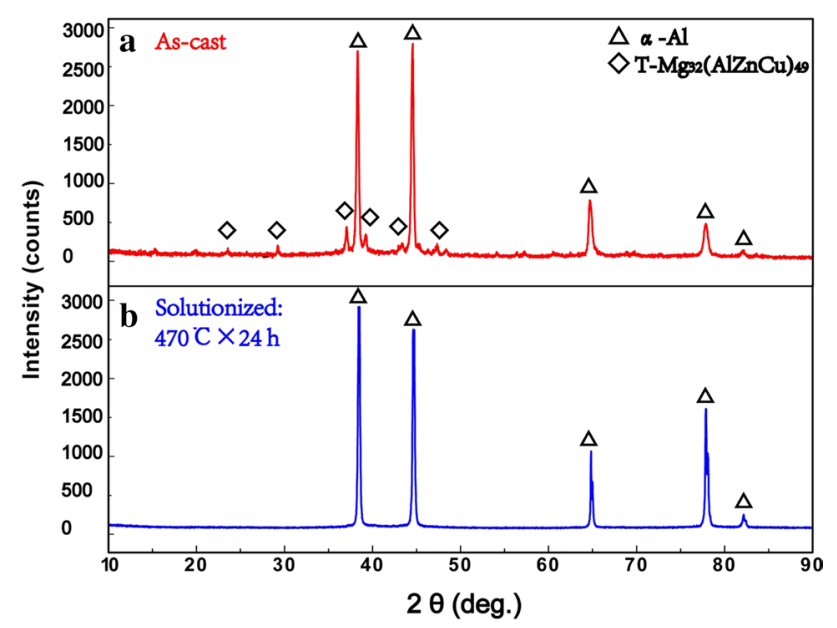

Fig. 3 XRD patterns of the as-cast $\mathrm{Al}-5.0 \mathrm{Mg}-3.0 \mathrm{Zn}-1.0 \mathrm{Cu}$ alloys: $\mathbf{a}$ under as-cast; $\mathbf{b}$ after solution treatment at $470{ }^{\circ} \mathrm{C}$ for $24 \mathrm{~h}$ in that only peaks of $\alpha-\mathrm{Al}$ were detected. This difference indicates that the T-phases were almost entirely dissolved into the $\mathrm{Al}$ matrix. The corresponding representative secondary phases and EDS results in the as-cast and solution treated alloys are shown in Fig. 4 and Table 2. The SEM microstructure and corresponding EDS maps further confirm the existence of the $\mathrm{T}_{-} \mathrm{M}_{\mathrm{g} 32}(\mathrm{AlZnCu})_{49}$ phase (point 2 in Fig. 4a and Table 2) and some Fe-containing phases (point 3 in Fig. 4a and Table 2) due to impurities. The formation of the $\mathrm{T}-\mathrm{Mg}_{32}(\mathrm{AlCuZn})_{49}$ phase was attributed to solute segregation during solidification. Several phases, such as the $\mathrm{T}-\mathrm{Mg}_{32}(\mathrm{AlZn})_{49}, \eta-\mathrm{MgZn}_{2}$ and $\mathrm{S}-\mathrm{Al}_{2} \mathrm{CuMg}$ phases can be formed in $\mathrm{Al}-\mathrm{Zn}-\mathrm{Mg}-\mathrm{Cu}$ alloys during solidification [14]. Furthermore, these phases can be dissolved in each other which can form more $\mathrm{T}-\mathrm{Mg}_{32}(\mathrm{AlZnCu})_{49}$ phases in the ascast microstructure. After solution treatment at $470{ }^{\circ} \mathrm{C}$ for $24 \mathrm{~h}$, most of the $\mathrm{T}$ phases were dissolved into matrix while the Fe-containing phases remained. The results of EDS point scanning show that the Fe-containing phase is most likely to be $\mathrm{Al}_{3} \mathrm{Fe}$ phase based on chemical composition.

The microstructural evolution of the Al-5.0Mg-3.0Zn-1.0Cu solution treated alloy at $470{ }^{\circ} \mathrm{C}$ for up to $48 \mathrm{~h}$ is shown in Fig. 5. The as-cast microstructure appeared to contain $\mathrm{Al}$ dendrites and network-like secondary phases, $\mathrm{T}-\mathrm{Mg}_{32}(\mathrm{AlZnCu})_{49}$ (Fig. 5a). After $0.25 \mathrm{~h}$ of solution
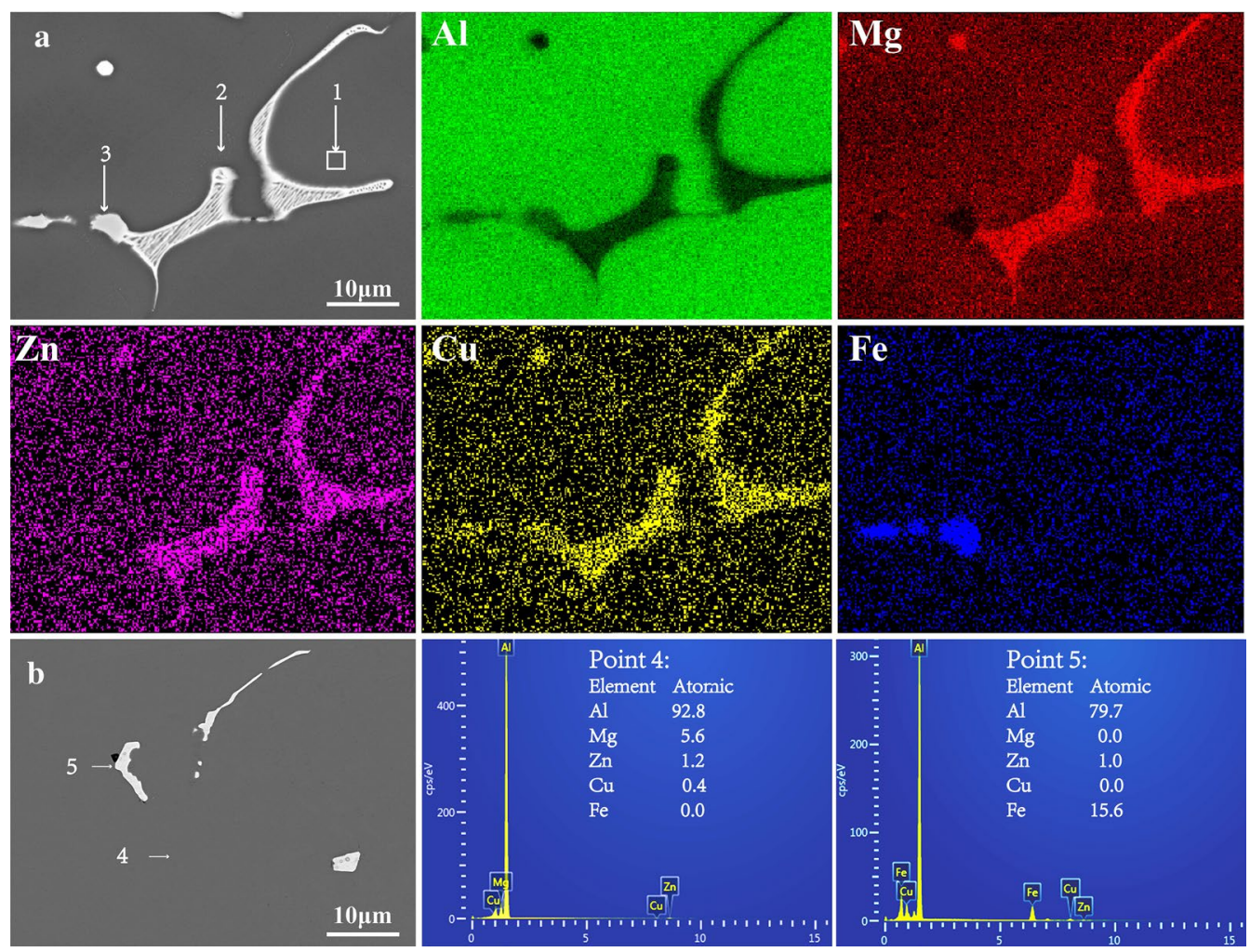

Fig. 4 a SEM microstructure of the as-cast alloy with corresponding elemental maps for $\mathrm{Al}, \mathrm{Mg}, \mathrm{Zn}, \mathrm{Cu}$ and Fe; $\mathbf{b}$ SEM microstructure after solution treatment at $470{ }^{\circ} \mathrm{C}$ for $24 \mathrm{~h}$ conditions with corresponding EDS results corresponding to points 4 and 5 
Table 2 EDS compositions for the secondary phase points in Fig. 4 (at\%)

\begin{tabular}{lllrlll}
\hline Point & $\mathrm{Al}$ & $\mathrm{Mg}$ & $\mathrm{Zn}$ & $\mathrm{Cu}$ & $\mathrm{Fe}$ & Identified phase \\
\hline Figure 4a, 1 & 97.5 & 2.1 & 0.3 & 0.1 & - & $\alpha-\mathrm{Al}$ \\
Figure 4a, 2 & 48.5 & 36.2 & 10.1 & 5.2 & - & $\mathrm{T}_{-\mathrm{Mg}_{32}(\mathrm{AlZnCu})_{49}}$ \\
Figure 4a, 3 & 71.4 & - & 0.9 & 2.5 & 25.2 & $\mathrm{Al}_{3} \mathrm{Fe}$ \\
Figure 4b, 4 & 92.8 & 5.6 & 1.2 & 0.4 & - & $\alpha-\mathrm{Al}$ \\
Figure 4b, 5 & 79.7 & - & 1.0 & 3.7 & 15.6 & $\mathrm{Al}_{3} \mathrm{Fe}$ \\
\hline
\end{tabular}

treatment (Fig. 5b), a high amount of the mesh $\mathrm{T}$ phase along Al grain boundary was observed. As the solution time was increased to $1 \mathrm{~h}$ (Fig. 5c), the amount of $\mathrm{T}$ phase decreased significantly, and the mesh-like structure evolved to form discontinuous particles. At $4 \mathrm{~h}$ of heat treatment (Fig. 5d), the amount of the T-phase further decreased when compared to that of the microstructure in Fig. 5a and the $\alpha$-phase has become small discontinuous linear like globular shapes. After $12 \mathrm{~h}$ of treatment time (Fig. 5e), the secondary phases reduced to small discontinuous spots throughout the surface. As the solution time further increased to 24, 36 and $48 \mathrm{~h}$ (Fig. 5f-h), the morphology of the residual phases appeared to remain generally constant. Thus, it can be concluded from the SEM observations depicted in Fig. 5 and described above, that the $\mathrm{T}$ phase was dissolved into Al matrix with the structure transforming from a mesh-like network structure to discontinuous particles. Previous studies show that the $S$-phase nucleates in $\eta$-phase for an initial $0.5 \mathrm{~h}$ during solution treatment and the transformation would be completed in $6 \mathrm{~h}$ [11]. Due to a higher $\mathrm{Cu}$ concentration in the $\mathrm{S}$ phase, it is easy to distinguish $\mathrm{S}$ phases from the $\eta$-phases. In this study, however, the $S$ phase was not found in $\mathrm{T}$ phase during microstructural evolution.

The area fraction of residual phases was determined with the statistical results as shown in Fig. 6. Overall, it decreased sharply within the initial $4 \mathrm{~h}$ before more gradually decreasing as the solution time was prolonged to $48 \mathrm{~h}$. According to results in Fig. 4, most of the T phases were dissolved in matrix as the solution time reached $12 \mathrm{~h}$. The disappearance of $\mathrm{T}$ phases indicates that there were no sites for the nucleation and growth of the $\mathrm{S}$ phase. Thus, the most likely time range for the transformation from the $\mathrm{T}$ phase to the $\mathrm{S}$ phase occurred between 0 and $12 \mathrm{~h}$. The composition of the residual phases was examined by EDS analysis at three distinct locations for the $0-12 \mathrm{~h}$ solution treatment time and the average composition of these three locations is plotted in Fig. 7. For the as-cast alloy, the concentration of $\mathrm{Mg}$ was much higher than that of $\mathrm{Zn}$ and $\mathrm{Cu}$ in the $\mathrm{T}$ phase. As the solution time increased to $1 \mathrm{~h}$, the $\mathrm{Mg}$ concentration began to decrease quite quickly, while the $\mathrm{Cu}$ concentration increased significantly. The sharp increase in $\mathrm{Cu}$ concentration has also been reported by Liu et al. [8] and Fan et al. [11] in previous studies. As the solution time reached 4 and $12 \mathrm{~h}$, the composition only changed minimally. Although there were significant changes in the concentration of alloying elements within the residual phase, the $\mathrm{Cu}$ concentration was much less than $25 \%$. Thus, the transformation of $S$ phase did not appear to occur by an EDS examination.

DSC curves of the $\mathrm{Al}-5.0 \mathrm{Mg}-3.0 \mathrm{Zn}-1.0 \mathrm{Cu}$ alloy after solution treatment at $470{ }^{\circ} \mathrm{C}$ for varying time intervals are shown in Fig. 8. Only one endothermic peak at $484{ }^{\circ} \mathrm{C}$ was detected regardless of the solution time. Compared with the as-cast material, the intensity of the endothermic peak decreased significantly as the solution time was increased to $4 \mathrm{~h}$. This intensity continued to decrease slightly until the time reached $24 \mathrm{~h}$ and the endothermic peak disappeared; which indicates that the majority of the $\mathrm{T}$ phases were dissolved into the Al matrix by this time. The results imply that $\mathrm{T}$ phases were first dissolved quickly at the initial stage and then fully dissolved into the Al matrix after a solution treatment of $24 \mathrm{~h}$. However, there were no endothermic peaks for the $\mathrm{S}-\mathrm{Al}_{2} \mathrm{CuMg}$ phase in the DSC curves, which implies further that the transformation from the $\mathrm{T}-\mathrm{Mg}_{32}(\mathrm{AlCuZn})_{49}$ phase to the $\mathrm{S}-\mathrm{Al}_{2} \mathrm{CuMg}$ phase does not occur.

Representative optical micrographs depicted in Fig. 9 show the coarsening of the grains as the solution time increased. After solution treatment for 4-48 h, the secondary phases were dissolved into matrix, which is in accordance with the results of the SEM observations (Fig. 5). Aside from the secondary phases, small grains disappeared which increased the average grain size as solution time increased. The average grain size was determined by examining $10 \mathrm{OM}$ images with the results shown in Fig. 10. The statistical results of grain size show that the average grain size increased by $49.5 \%$ from $\sim 275$ to $\sim 411 \mu \mathrm{m}$ when the solution time was increased from 4 to 48 h. Furthermore, the coarsening rate appears to be relatively slow at the beginning but increases quickly at the end of solution treatment. This change may be related to the retardation of grain boundary movement caused by the secondary phase. At the beginning, many $\mathrm{T}$ phases exist around the grain boundaries, which hinders their movement. As a result, the coarsening rate is relatively slow. However, this retardation disappears during the dissolution of the secondary phases, leading to a fast coarsening rate. 


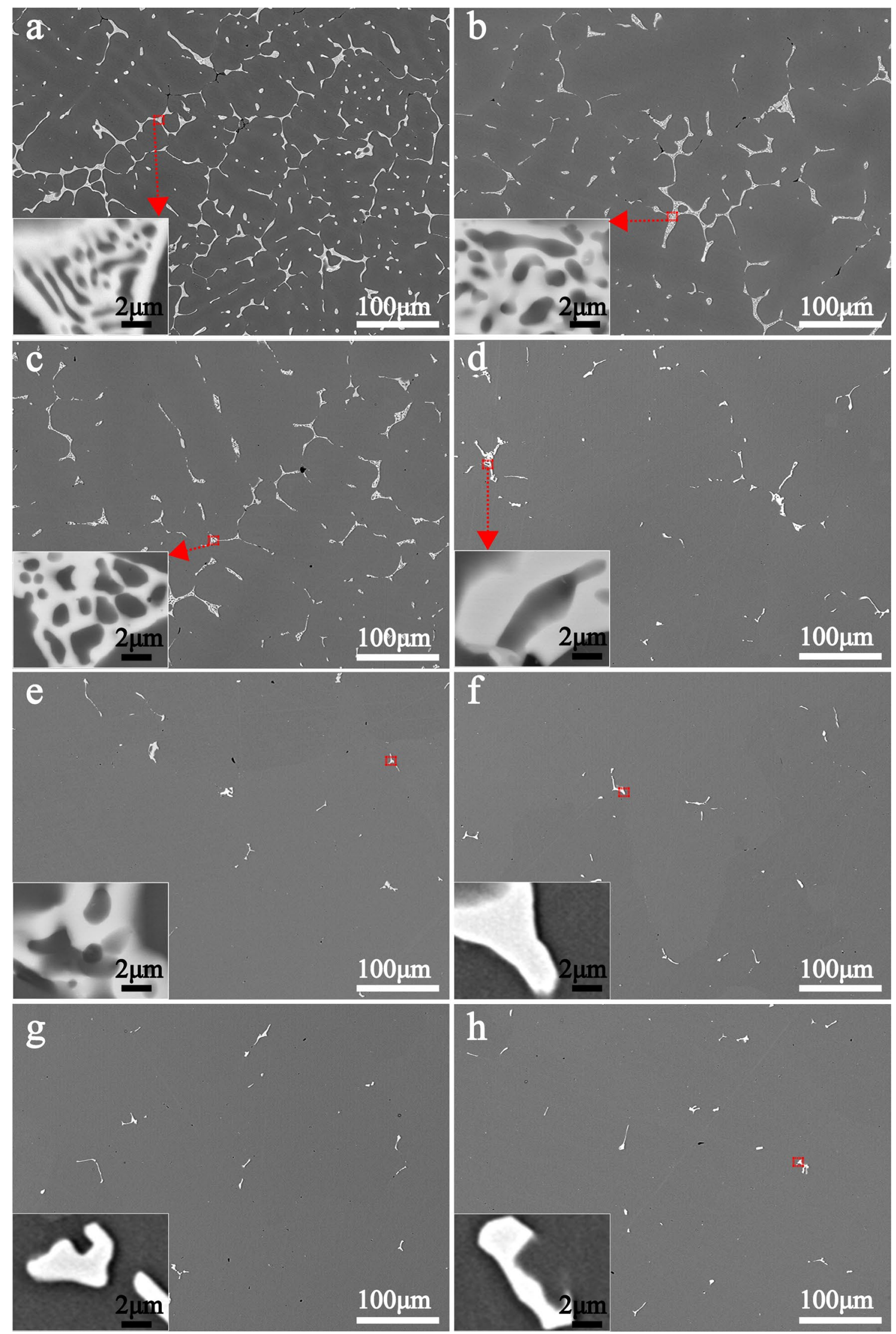


4Fig. 5 SEM images depicting the microstructural evolution of the studied alloy after solution treatment at $470{ }^{\circ} \mathrm{C}$ for the following durations: a as-cast conditions, b $0.25 \mathrm{~h}, \mathbf{c} 1 \mathrm{~h}, \mathbf{d} 4 \mathrm{~h}, \mathbf{e ~} 12 \mathrm{~h}, \mathbf{f} 24 \mathrm{~h}, \mathbf{g}$ $36 \mathrm{~h}, \mathbf{h} 48 \mathrm{~h}$

\subsection{Mechanical Properties}

From Fig. 11a, b, both strength and elongation increased sharply within the first hour, increased slowly onwards and decreased slightly with increasing solution time after a plateau was reached. After solution treatment at $470{ }^{\circ} \mathrm{C}$ for $24 \mathrm{~h}$, the ultimate tensile strength, yield strength and elongation increased from 228.6 MPa, 204.1 MPa, and 2.0\% to $431.6 \mathrm{MPa}, 270.1 \mathrm{MPa}$, and $19.4 \%$, respectively. Compared with the tensile properties, impact toughness presented a similar trend (as shown with red line in Fig. 11c). The impact toughness increased from 14.1 to $154.7 \mathrm{~kJ} /$ $\mathrm{m}^{2}$ with increasing solution time from 0 to $24 \mathrm{~h}$, and then decreased to $131.9 \mathrm{~kJ} / \mathrm{m}^{2}$ with further increasing solution time to $48 \mathrm{~h}$. Both the tensile properties and impact toughness reached the highest value when the alloy was solution treated at $470{ }^{\circ} \mathrm{C}$ for $24 \mathrm{~h}$.

Figure $11 \mathrm{c}$ also shows the changes in yield strength, elongation and impact toughness with increasing solution treatment durations. It appears that although all three had a similar change trend, the trend of impact toughness and elongation was more synchronized. A regression analysis through the data points of the elongation and impact toughness (using data from Fig. 11c) showed that the impact toughness was a function of the elongation (Fig. 11d) and can be represented by the following equation:

$\mathrm{IT}=8.43 \mathrm{EL}-3.46$

where IT represents the impact toughness $\left(\mathrm{kJ} / \mathrm{m}^{2}\right)$, and EL represents the elongation (\%). Similar results were also reported in $\mathrm{Mg}-6 \mathrm{Gd}-3 \mathrm{Y}-0.5 \mathrm{Zr}$ cast alloys by Wang et al. [3]. These results show that the impact toughness appears to be more closely related to the elongation than yield strength. Thus, it can be interpreted that increasing the ductility will improve the impact toughness significantly.

To better understand the properties of the studied alloy under solution treatment, the properties of the peak-aged $\mathrm{Al}-5.0 \mathrm{Mg}-3.0 \mathrm{Zn}-1.0 \mathrm{Cu}$ alloy was also subjected to tensile and impact testing. The results of these tests are listed in Table 3. Compared with the peak-aged alloy, the solution treated alloy displays a much higher impact toughness. To better illustrate the effect of solution treatment on the mechanical properties of this alloy, the properties of $\mathrm{Al}-7.2 \mathrm{Si}-0.3 \mathrm{Mg}$ (A356, a widely used cast aluminum alloy) [16] and wrought $\mathrm{Al}-6.0 \mathrm{Mg}-0.7 \mathrm{Mn}$ (5E06, a 5xxx aluminum alloy) [17] are also displayed in Table 3 for comparison. Both strength and impact toughness of the solution treated alloy are much higher than that of $\mathrm{Al}-7.2 \mathrm{Si}-0.3 \mathrm{Mg}$ and that its properties even reach the performance level of wrought $\mathrm{Al}-6.0 \mathrm{Mg}-0.7 \mathrm{Mn}$. Thus, after optimal solution treatment, the studied alloy appears to possess an excellent combination of strength and impact toughness comparable to high performance alloys.

As illustrated in Fig. 12a, b, numerous micro-cracks were observed over the entire surface, suggesting a brittle fracture for the as-cast alloys. EDS results indicate that the phases with micro-cracks (points 2 and 3 in Fig. 12c and Table 4) had a composition like that of the $\mathrm{T}$ phase (eutectic compounds). As $T$ phases are brittle, micro-cracks tend to nucleate within them. The main crack propagated rapidly across the weak eutectics where it once originated, which gave rise to a lower impact toughness. After optimal solution treatment at $470{ }^{\circ} \mathrm{C}$ for $24 \mathrm{~h}$, large amounts tearing ridges and shear bands appeared over the entire sample (Fig. 12d-f), indicating a ductile feature. This observation means that for the optimally treated sample, the impact load caused the specimen to undergo considerable plastic deformation, which resulted in a higher impact toughness. The transformation from brittle to ductile features is also in agreement with the results of the microstructural evolution in Fig. 5. The dissolution of $\mathrm{T}$ phases caused by solution treatment will reduces the nucleation of micro-cracks and thereby improve ductility, leading to a higher impact toughness.

\section{Discussion}

\subsection{Effect of Cu Content on S-Phase Transformation During Solution Treatment}

During the solution or homogenization process of $\mathrm{Al}-\mathrm{Mg}-\mathrm{Zn}-\mathrm{Cu}$ alloys, the phase transformation from $\mathrm{T}-\mathrm{Al}_{32}(\mathrm{AlZnCu})_{49} / \eta-\mathrm{Mg}(\mathrm{ZnCuAl})_{2}$ phases to $\mathrm{S}-\mathrm{Al}_{2} \mathrm{CuMg}$ often occurs. A recent study has shown that when the $\mathrm{Zn}$ content exceeds $8 \%$, S phase transformation does not occur but when the $\mathrm{Zn}$ content is lower than $8 \%$, this transformation will occur [8]. However, the S-phase transformation was not detected in this study, even when the $\mathrm{Zn}$ content was 3\% (much less than 8\%). This indicates that there are other factors affecting the S-phase transformation other than Zn content.

Considering the difference in compositions of the $\mathrm{T}-\mathrm{Mg}_{32}(\mathrm{AlZnCu})_{49} / \eta-\mathrm{Mg}(\mathrm{ZnCuAl})_{2}$ and $\mathrm{S}-\mathrm{Al}_{2} \mathrm{CuMg}$ phase, it is obvious that $\mathrm{Cu}, \mathrm{Mg}$ and $\mathrm{Zn}$ will influence the phase transformation. Since the S-phases nucleate and grow into the $\mathrm{T} / \eta$-phases and the concentration of $\mathrm{Mg}$ in $\mathrm{T} / \eta$-phases is high, the supply of $\mathrm{Cu}$ for phase transformation and the disappearance of $\mathrm{Zn}$ become two key factors. To better illustrate the effect of $\mathrm{Cu}$ and $\mathrm{Zn}$ content on the 


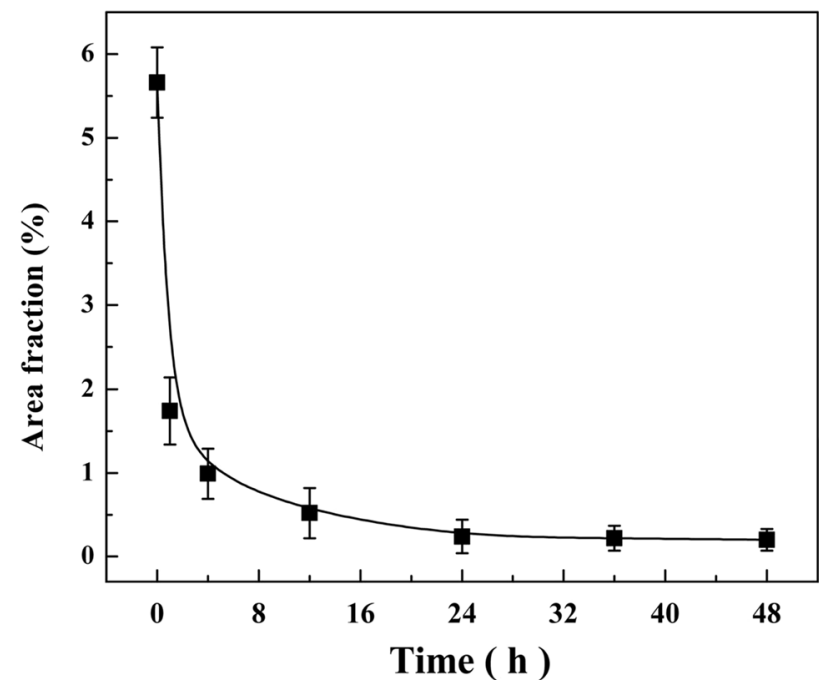

Fig. 6 Area fraction of the residual phase vs solution time during solution treatment at $470{ }^{\circ} \mathrm{C}$

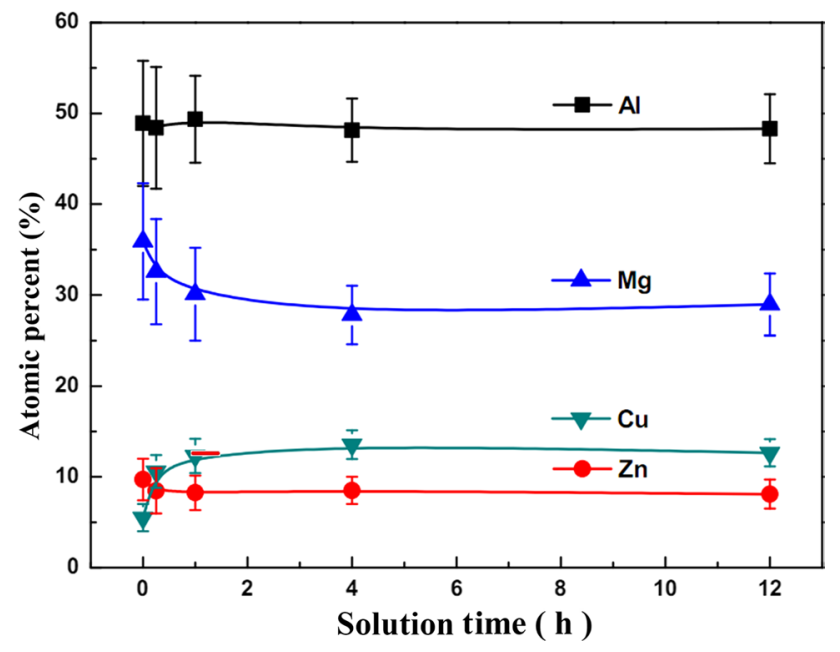

Fig. 7 Variation of $\mathrm{Al}, \mathrm{Mg}, \mathrm{Zn}$ and $\mathrm{Cu}$ concentrations in the residual phases at different solution time during solution treatment at $470{ }^{\circ} \mathrm{C}$

likelihood of the S-phase transformation occurring during homogenization (at temperatures ranging from 460 to $480{ }^{\circ} \mathrm{C}$ ), a correlational summary graph for $\mathrm{Cu}$ and $\mathrm{Zn}$ content was constructed from previous studies (Fig. 13). As this figure illustrates, most alloys in which phase transformation occurred is when $\mathrm{Cu}$ content is greater than $1.5 \%$ and $\mathrm{Zn}$ content is less than $8 \%$. Conversely, this transformation was not observed (except for one case [20]) when the $\mathrm{Cu}$ content is less than $1.5 \%$ and the $\mathrm{Zn}$ content was greater than $8 \%$. This is in accordance with results reported by Liu et al. [8], which also found that the transformation does not tend to occur when the $\mathrm{Zn}$ content exceeds $8 \%$. There has not been much research on how the $\mathrm{Cu}$ content affects the S-phase transformation. To achieve

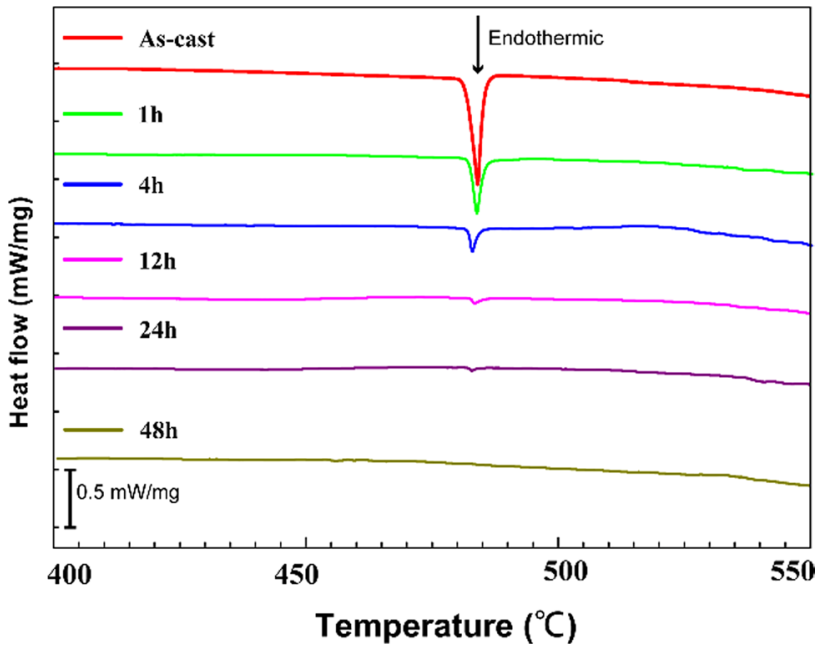

Fig. 8 DSC curves of the $\mathrm{Al}-5.0 \mathrm{Mg}-3.0 \mathrm{Zn}-1.0 \mathrm{Cu}$ alloys after solution treatment at $470{ }^{\circ} \mathrm{C}$ for $0 \mathrm{~h}$ (as-cast), $1 \mathrm{~h}, 4 \mathrm{~h}, 12 \mathrm{~h}, 24 \mathrm{~h}, 48 \mathrm{~h}$

this transformation, two aspects are considered: first, thermodynamics and second, composition.

Firstly, the S-phase transformation must conform to the laws of thermodynamics. If $\mathrm{S}$ phase can be formed under equilibrium conditions, it would mean that the transformation tends to occur during solution treatment. To further examine this phenomenon, the isothermal cross sections of $\mathrm{Al}-\mathrm{Mg}-\mathrm{Zn}-\mathrm{Cu}$ alloy phase diagrams with a temperature of $470{ }^{\circ} \mathrm{C}$ and $\mathrm{Cu}$ contents of $1.0 \%, 1.5 \%$ and $2.0 \%$ were calculated using Pandat 2019 software (Fig. 14). The results show that the composition of $\mathrm{Al}-5.0 \mathrm{Mg}-3.0 \mathrm{Zn}-1.0 \mathrm{Cu}$ is in the $\mathrm{Fcc}+\mathrm{S}$ phase region, which indicates that the $\mathrm{Al}-5.0 \mathrm{Mg}-3.0 \mathrm{Zn}-1.0 \mathrm{Cu}$ alloy tends to undergo an S-phase transformation. Additionally, as the $\mathrm{Cu}$ content increases, the area of the $\mathrm{Fcc}+\mathrm{S}$ region increases significantly, indicating that the thermodynamic tendency to form the $\mathrm{S}$ phase increases with an increase in $\mathrm{Cu}$ content. The phase diagram results can explain why the $\mathrm{S}$-phase transformation occurs in many $\mathrm{Al}-\mathrm{Mg}-\mathrm{Zn}-\mathrm{Cu}$ alloys and suggests that the $\mathrm{Cu}$ content also affects this transformation.

Secondly, the nucleation and growth of the S-phase requires certain compositions of $\mathrm{Cu}$ within the residual phases. A certain amount of $\mathrm{Cu}$ through diffusion must be accumulated, which is related to the $\mathrm{Cu}$ content. The increase in $\mathrm{Cu}$ concentration in residual phases is determined by the cooperative diffusion behavior of $\mathrm{Cu}, \mathrm{Mg}$ and $\mathrm{Zn}$ elements. The diffusion behavior of $\mathrm{Cu}, \mathrm{Mg}$ and $\mathrm{Zn}$ can be described by Fick's first law expressed as [13]:

$J=-D \frac{\mathrm{d} \rho}{\mathrm{d} x}$

where $D$ is diffusion coefficient $\left(\mathrm{m}^{2} / \mathrm{s}\right), \rho$ is the concentration, $\frac{\mathrm{d} \rho}{\mathrm{d} x}$ is the concentration gradient, and $J$ is diffusive flux. 

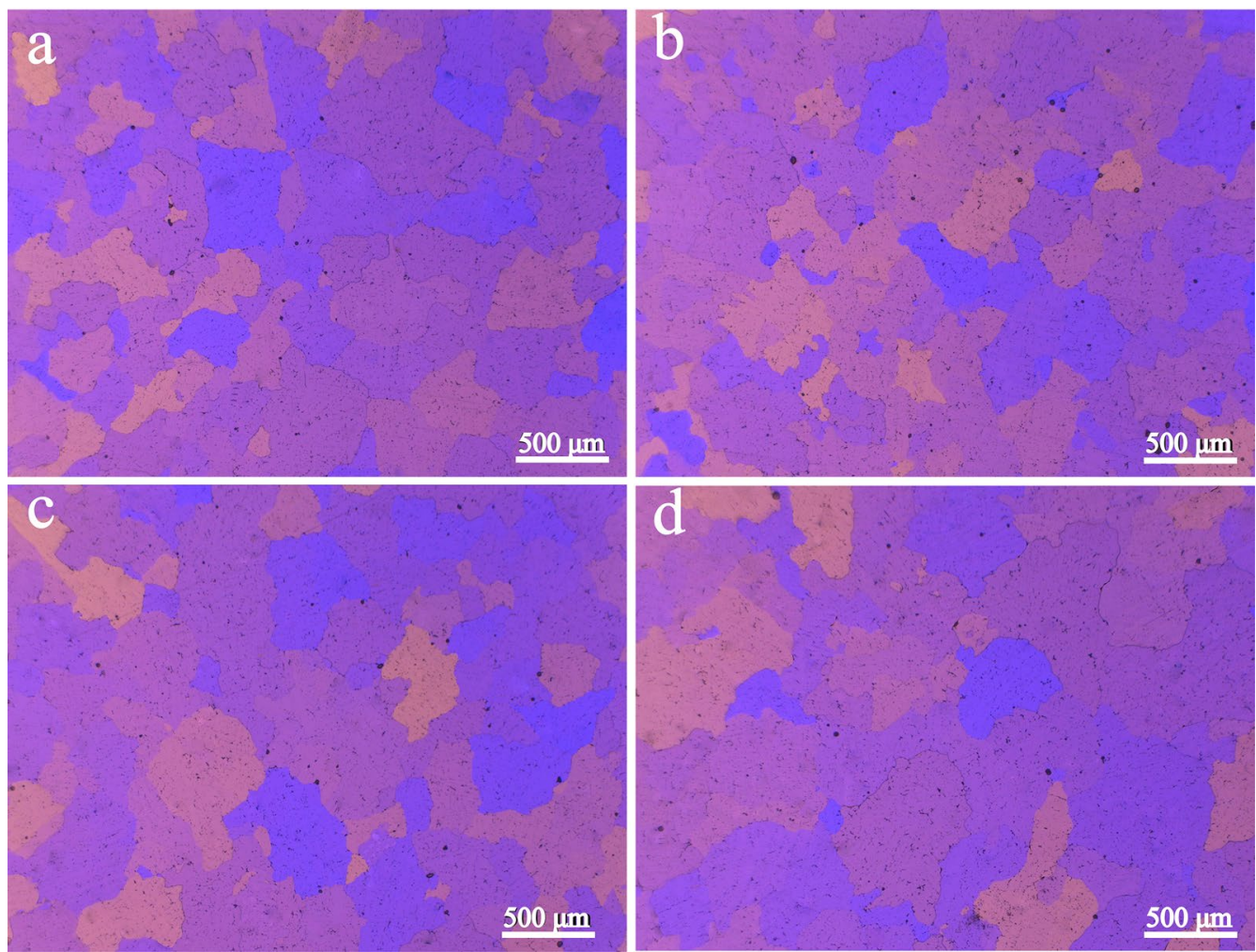

Fig. 9 Representative optical micrographs of the studied alloys after solution treatment at $470{ }^{\circ} \mathrm{C}$ for different time: a $4 \mathrm{~h}, \mathbf{b} 12 \mathrm{~h}, \mathbf{c} 24 \mathrm{~h}, \mathbf{d} 48 \mathrm{~h}$

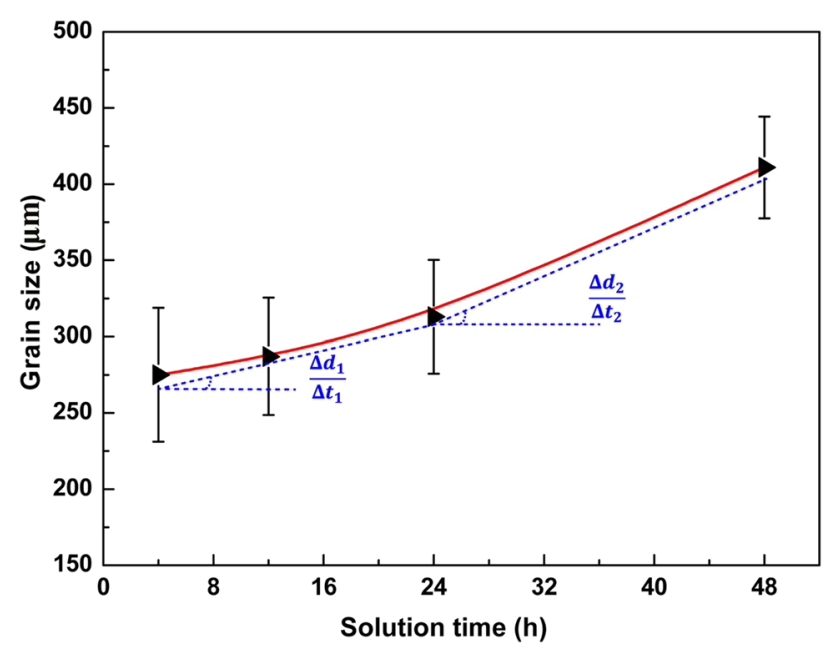

Fig. 10 Grain size versus solution treatment time at $470{ }^{\circ} \mathrm{C}$ for the studied alloys

According to Eq. (2), the diffusive flux $(J)$ is proportional to diffusion coefficient and the concentration gradient. The diffusion coefficient of $\mathrm{Cu}$ is much lower than that of $\mathrm{Mg}$ and $\mathrm{Zn}$. $\mathrm{Xu}$ et al. [13] determined the solid diffusion coefficients of $\mathrm{Cu}$, $\mathrm{Mg}$ and $\mathrm{Zn}$ in the $\mathrm{Al}$ matrix to be $1.95 \times 10^{-14}, 5.15 \times 10^{-14}$ and $9.58 \times 10^{-14} \mathrm{~m}^{2} / \mathrm{s}$, respectively, when the solution temperature is $470{ }^{\circ} \mathrm{C}$. Due to the higher concentration and diffusion coefficients of $\mathrm{Mg}$ and $\mathrm{Zn}$ in $\mathrm{T} / \eta$-phases, the diffusive fluxes of $\mathrm{Mg}$ and $\mathrm{Zn}$ are much larger than that of $\mathrm{Cu}$. Thus, the solubility of $\mathrm{Mg}$ and $\mathrm{Zn}$ in the residual phase decreases rapidly while the solubility of $\mathrm{Cu}$ increases rapidly. With the continuous accumulation of $\mathrm{Cu}$, the concentration gradient of $\mathrm{Cu}$ increases, resulting in an increase in diffusive flux of $\mathrm{Cu}$. Thus, the increasing rate of $\mathrm{Cu}$ concentration decreases. Finally, the diffusion behavior among $\mathrm{Mg}, \mathrm{Zn}$ and $\mathrm{Cu}$ reach a dynamic equilibrium and maintain a relatively stable solubility until they are completely dissolved into the matrix. When the content of $\mathrm{Cu}$ is less than $1.5 \%$, the dynamic equilibrium concentration of $\mathrm{Cu}$ in the residual phase is much lower than $25 \%$, thus the transformation will not occur. Increasing the $\mathrm{Cu}$ content (to more than $1.5 \%$ ) can improve the solubility of $\mathrm{Cu}$ in the $\mathrm{Al}$ matrix during solution treatment and thus reduce the concentration gradient of $\mathrm{Cu}$ between the residual phase and the $\mathrm{Al}$ matrix. The decrease in concentration gradient will benefit the accumulation of $\mathrm{Cu}$ in the residual phase and thus increase the concentration of $\mathrm{Cu}$, which promotes S-phase transformation.

\subsection{Effect of Solution Treatment on Yield Strength and Impact Toughness}

Based on the results of the tensile tests in Fig. 11, solution treatment appears to both increase the strength and ductility 

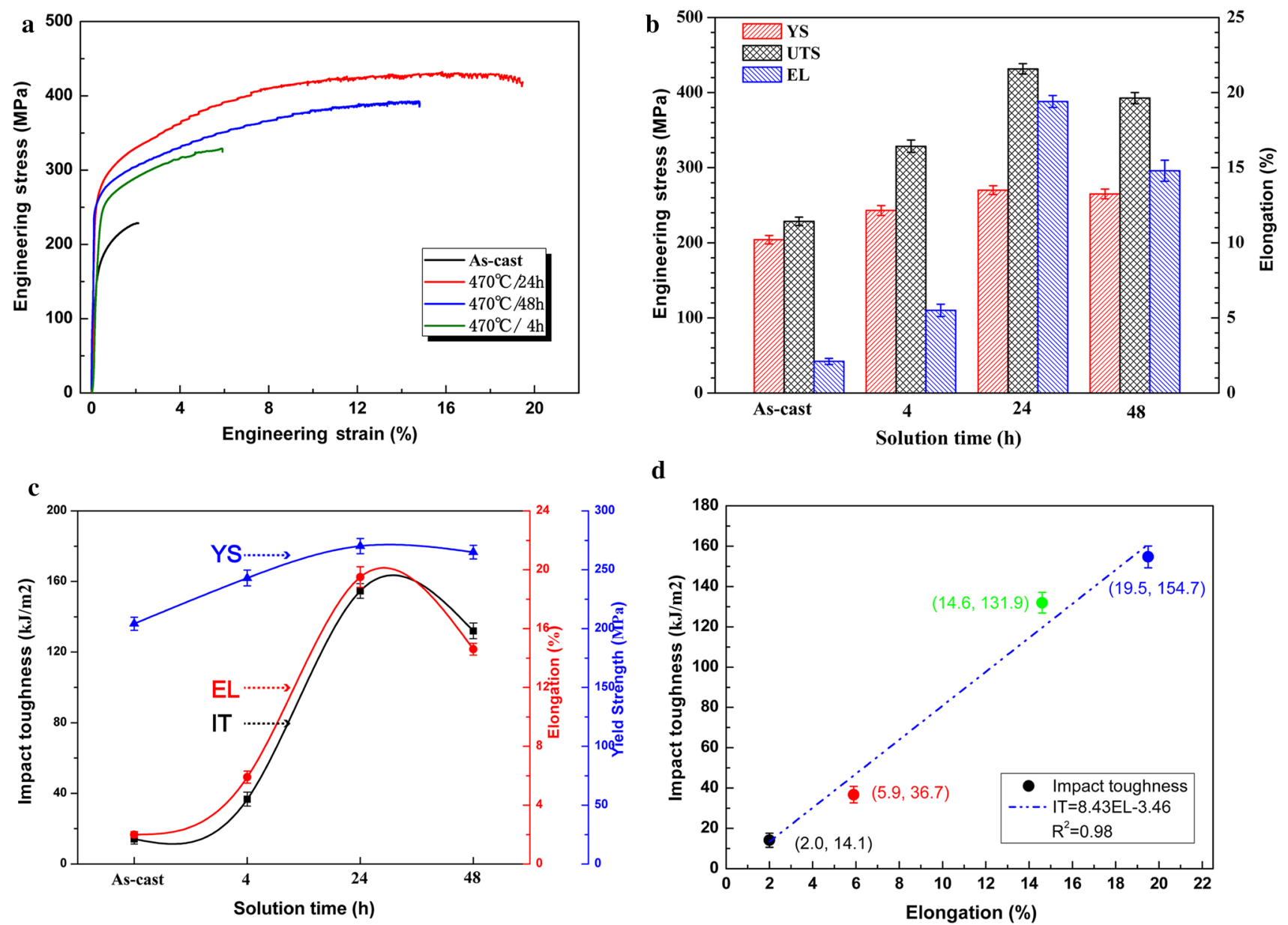

d

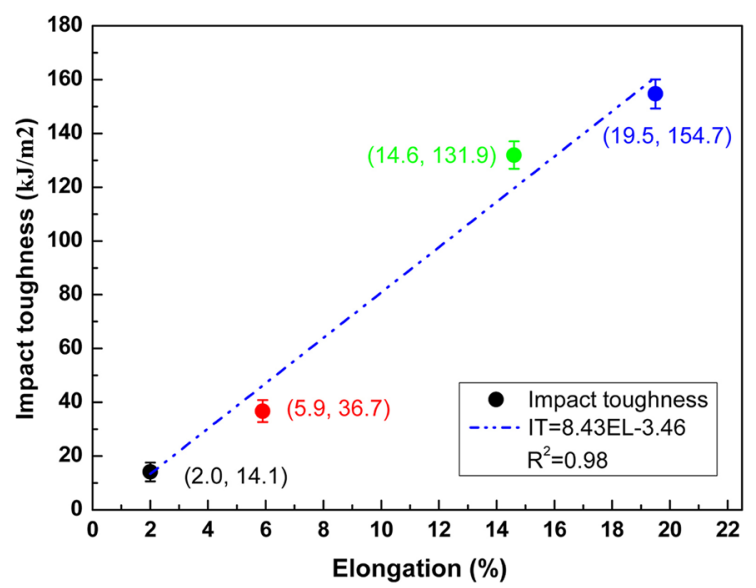

Fig. 11 Change in mechanical properties of the $\mathrm{Al}-5.0 \mathrm{Mg}-3.0 \mathrm{Zn}-1.0 \mathrm{Cu}$ alloys for increasing solution treatment time at $470{ }^{\circ} \mathrm{C}$, including: a typical tensile curves; $\mathbf{b}$ tensile properties; $\mathbf{c}$ variations of impact toughness, yield strength and elongation with solution time; $\mathbf{d}$ relationship between the impact toughness and the elongation

Table 3 A comparison of mechanical properties of the studied alloy with typical Al-Si casting alloy and Al-Mg wrought alloys [16, 17]

\begin{tabular}{llllrrr}
\hline Alloys & State & UTS (MPa) & YS (MPa) & EL $(\%)$ & IT $\left(\mathrm{kJ} / \mathrm{m}^{2}\right)$ & Refs. \\
\hline Al-5.0Mg-3.0Zn-1.0Cu & Gravity casting +T4 & 431.6 & 270.1 & 19.4 & 154.7 & Present study \\
Al-5.0Mg-3.0Zn-1.0Cu & Gravity casting +T6 & 490.1 & 423.3 & 8.3 & 104.3 & Present study \\
Al-7.2Si-0.3Mg & Gravity casting +T6 & 275.0 & 200.0 & 6.9 & 70.0 & {$[16]$} \\
Al-6.0Mg-0.7Mn & Cold-rolled & 526.2 & 416.0 & 10.5 & 152.0 & {$[17]$} \\
\hline
\end{tabular}

of the alloy and overcome the shortcomings of traditional methods which reducing strength in exchange for high ductility. Comparing the as-cast sample and optimally solution treated sample, the yield strength increased by $66.0 \mathrm{MPa}$ (from 204.1 to $270.1 \mathrm{MPa}$ ), which can be calculated quantitatively based on the solid solution strengthening effect produced by each alloying element.

During solution treatment at $470{ }^{\circ} \mathrm{C}$, T phases were gradually dissolved into the $\mathrm{Al}$ matrix, leading to an incremental increase in the concentrations of $\mathrm{Mg}, \mathrm{Zn}$ and $\mathrm{Cu}$ in the matrix. As the solid solubility of solute atoms in the matrix is enhanced, the effect of solid solution strengthening is improved. The contribution of the dislocation motion resistance produced by the solute atoms on the yield strength can be approximated as [28]:

$\Delta \sigma_{\mathrm{ss}}=M G b \varepsilon_{\mathrm{ss}}^{\frac{3}{2}} \sqrt{c}$

where $\Delta \sigma_{\mathrm{ss}}$ is the change in solid solution strengthening (for the solutes $\mathrm{Mg}, \mathrm{Zn}$ and $\mathrm{Cu}$ ). $M$ is the mean orientation factor, 

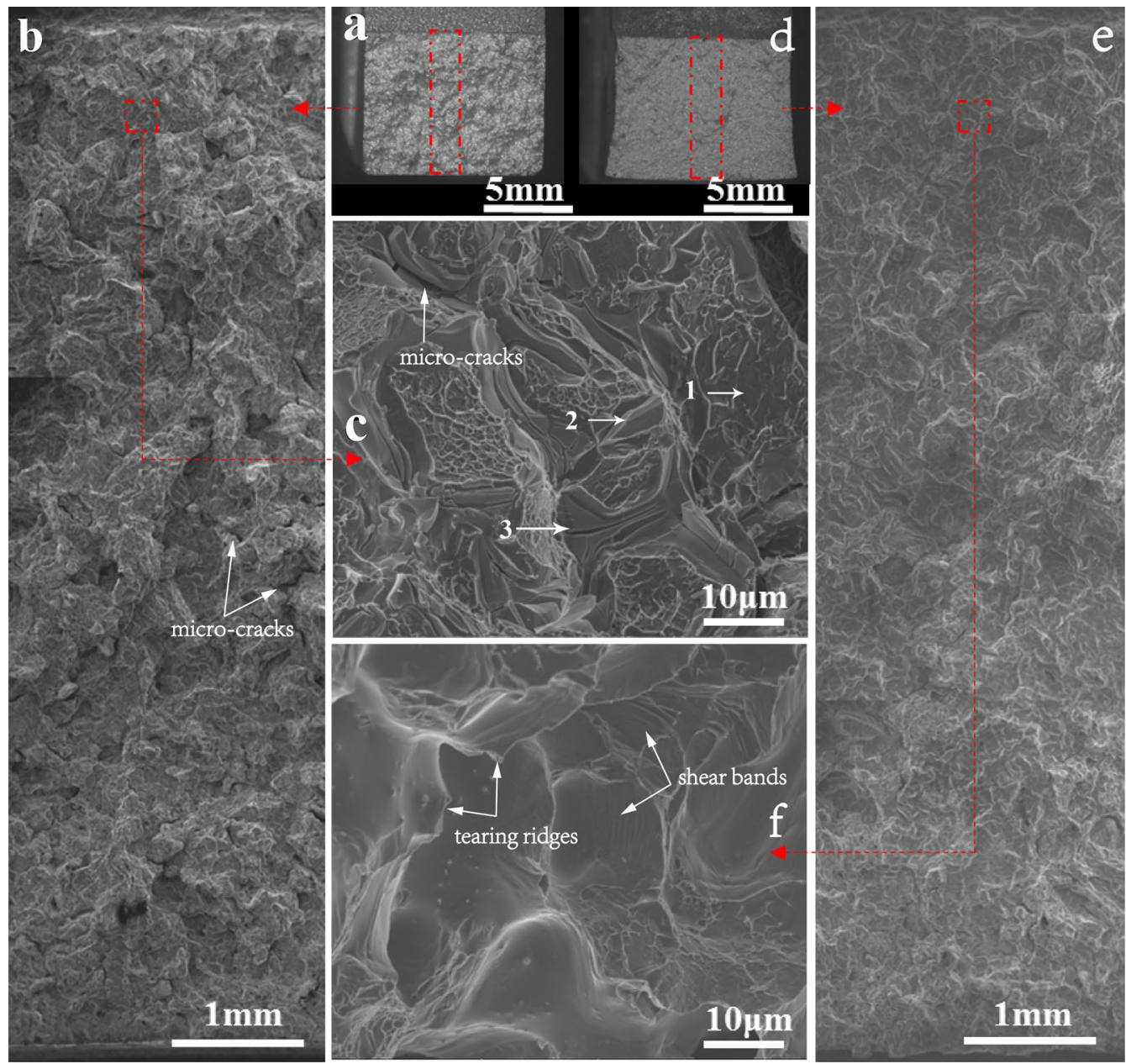

Fig. 12 Impact fracture surfaces of the $\mathrm{Al}-5.0 \mathrm{Mg}-3.0 \mathrm{Zn}-1.0 \mathrm{Cu}$ alloys under: $\mathbf{a}-\mathbf{c}$ as-cast; $\mathbf{d}-\mathbf{f}$ optimal solution treatment conditions

Table 4 EDS compositions for the secondary phase points in Fig. 12 (at\%)

\begin{tabular}{llrrr}
\hline Point & $\mathrm{Al}$ & $\mathrm{Mg}$ & \multicolumn{1}{c}{$\mathrm{Zn}$} & $\mathrm{Cu}$ \\
\hline Figure 12c, 1 & 97.5 & 2.1 & 0.3 & 0.1 \\
Figure 12c, 2 & 48.5 & 36.2 & 10.1 & 5.2 \\
Figure 12c, 3 & 51.3 & 31.4 & 12.6 & 4.7 \\
\hline
\end{tabular}

$G$ is shear modulus, $b$ is the magnitude of the burgers vector, $\varepsilon$ is the lattice strain and $c$ is concentration. According to the solute concentrations of $\mathrm{Mg}, \mathrm{Zn}$ and $\mathrm{Cu}$ in Table 2, the incremental increase in $\mathrm{Mg}, \mathrm{Zn}$ and $\mathrm{Cu}$ concentration is $3.07 \mathrm{wt} \%, 2.14 \mathrm{wt} \%$, and $0.7 \mathrm{wt} \%$, respectively. The addition in yield strength is $18.6,2.9$, and $13.8 \mathrm{MPa}$ due to an incremental increase in 1 by $\mathrm{wt}_{\%}$ of $\mathrm{Mg}, \mathrm{Zn}$ and $\mathrm{Cu}$ in the matrix [5]. As a result, the calculated strength from the solid solution strengthening effect is about 73.0 MPa. This means that, after solution treatment, the yield strength will increase

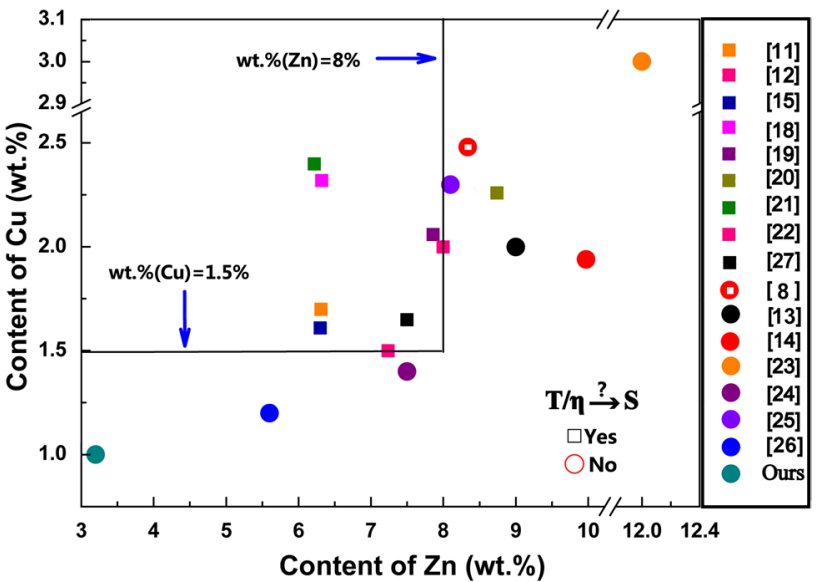

Fig. 13 A summary graph indicating the phase transformation from the $\mathrm{T}-\mathrm{Mg}_{32}(\mathrm{AlZnCu})_{49} / \eta-\mathrm{Mg}(\mathrm{ZnCuAl})_{2}$ phases to $\mathrm{S}-\mathrm{Al}_{2} \mathrm{CuMg}$ phase of the alloys as functions of $\mathrm{Cu}$ content and $\mathrm{Zn}$ content $[8,11-15$, 18-27] 


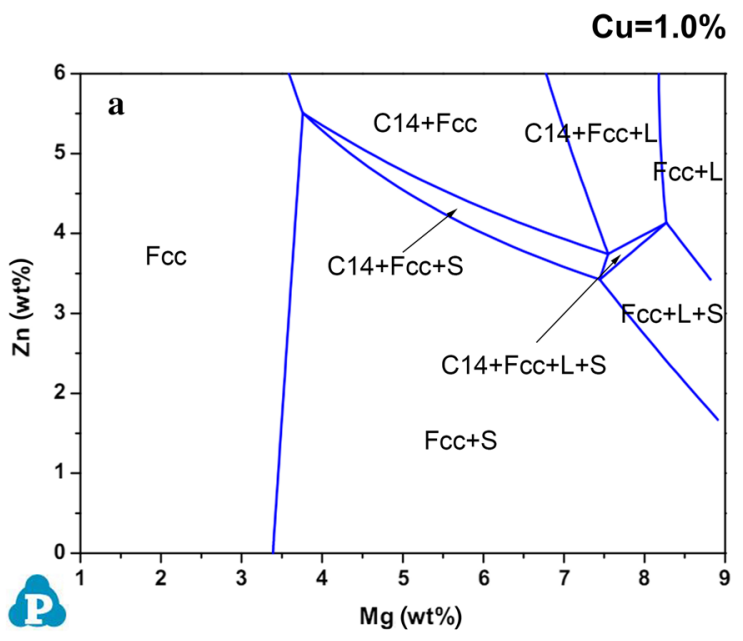

$\mathrm{Cu}=1.5 \%$
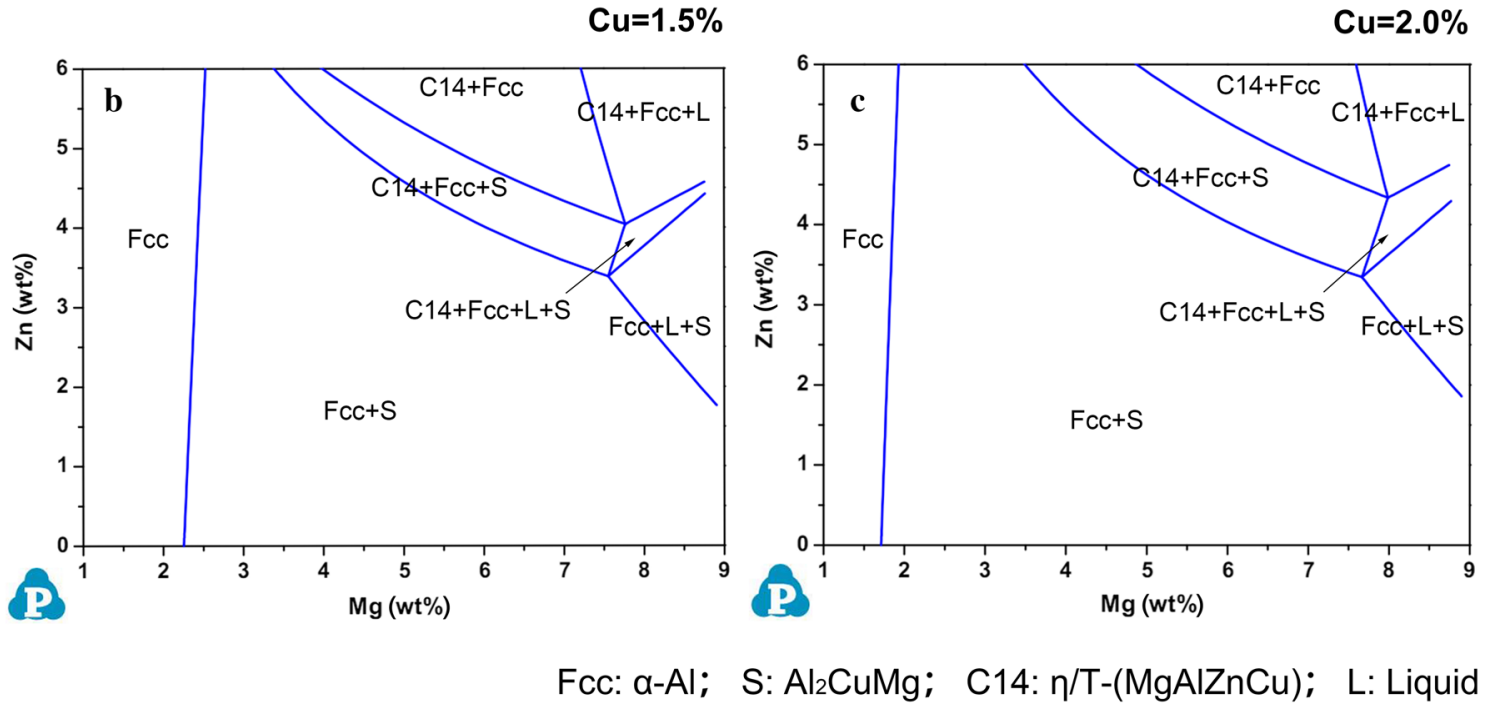

Fig. 14 Isothermal cross sections of $\mathrm{Al}-\mathrm{Zn}-\mathrm{Mg}-\mathrm{Cu}$ phase diagrams at $470{ }^{\circ} \mathrm{C}$ near the $\mathrm{Al}$ area with increasing $\mathrm{Cu}$ content from a $1.0 \%$ to, b $1.5 \%$ to, c $2.0 \%$. In the phase diagrams, Fcc, S, C14 and $\mathrm{L}$ represent $\alpha-\mathrm{Al}, \mathrm{S}-\mathrm{Al}{ }_{2} \mathrm{CuMg}, \eta / \mathrm{T}-(\mathrm{MgAlZnCu})$ and liquid, respectively

by $73.0 \mathrm{MPa}$, which is approximately equal to the experimental increase of 66.0 MPa.

With the disappearance of the $\mathrm{T}$ phase and the absence of the S phase, the ductility of the alloy was also significantly improved, which is consistent with the results of other articles $[14,27,29]$. According to these studies, the significant increase in ductility is attributed to disappearance of brittle $T / \eta$ phases. It is worth noting that in this study a linear relationship between impact toughness and elongation was found, referring to in Eq. (1). The possible explanation behind this relationship is that although the impact toughness depends on strength and ductility $[3,16]$, the yield strength in this study did not change much, with an increase from 204.1 to 270.1 MPa. Thus, the main factor influencing the impact toughness is ductility. As the ductility improves, the path of crack propagation during impacts become more resistant, and thus can absorb more energy. As a result, the relationship between the impact toughness and the elongation tends to obey a linear equation.

\section{Conclusions}

In this study, an $\mathrm{Al}-5.0 \mathrm{Mg}-3.0 \mathrm{Zn}-1.0 \mathrm{Cu}$ cast alloy was prepared by permanent gravity casting and the effects of solution treatment on the microstructure, tensile properties and impact toughness were investigated. The main conclusions are as follow:

1. The as-cast microstructure consists of $\mathrm{Al}$ dendrites and a network-like second phase $\mathrm{T}-\mathrm{Mg}_{32}(\mathrm{AlZnCu})_{49}$. As the solution treatment proceeded, the presence of $\mathrm{T}$ phases decreased sharply within the initial $4 \mathrm{~h}$ and the morphol- 
ogy evolved from a network-like structure to discontinuous particles.

2. During solution treatment, the transformation from the $\mathrm{T}$ phase to the $\mathrm{S}-\mathrm{Al}_{2} \mathrm{CuMg}$ phase was not discovered, although a significant increase in $\mathrm{Cu}$ concentration in the residual phase was detected. The lack of this transformation can be attributed to the cooperative diffusion behaviors of $\mathrm{Cu}, \mathrm{Mg}$ and $\mathrm{Zn}$ elements.

3. As solution treatment proceeded, both the tensile properties and impact toughness increased quickly, before reaching a peak and gradually decreasing. After optimal solution treatment at $470{ }^{\circ} \mathrm{C}$ for $24 \mathrm{~h}$, the alloy exhibited excellent mechanical properties with the UTS, YS, EL and impact toughness being 431.6 MPa, 270.1 MPa, $19.4 \%$ and $154.7 \mathrm{~kJ} / \mathrm{m}^{2}$, which are comparable to that of wrought $\mathrm{Al}-6.0 \mathrm{Mg}-0.7 \mathrm{Mn}$ alloy.

4. Although the impact toughness of the alloy is related to its yield strength and ductility, the impact toughness and elongation show a closer relationship due to a small change in yield strength (from 204.1 to 270.1 MPa). The relationship between the impact toughness (IT) and elongation (EL) appears to obey the linear equation: $\mathrm{IT}=8.43 \mathrm{EL}-3.46$.

5. During impact fracture, micro-cracks easily nucleate and propagate along brittle residual phases, greatly reducing the impact toughness. Compared with the as-cast alloy, solution treatment appeared to dissolve most of the eutectic phases, resulting in a much better impact toughness.

Acknowledgements The authors are grateful to the United Fund of National Natural Science Foundation of China and Yunnan Province (No. U1902220) and the National Natural Science Foundation of China (No. 51674166).

\section{References}

[1] B. Lin, W. Zhang, Z. Lou, D. Zhang, Y. Li, Mater. Des. 59, 10 (2014)

[2] H. Tang, Q. Wang, C. Lei, B. Ye, K. Wang, H. Jiang, W. Ding, X. Zhang, Z. Lin, J. Zhang, J. Alloys Compd. 801, 596 (2019)
[3] Q. Wang, L. Xiao, W. Liu, H. Zhang, W. Cui, Z. Li, G. Wu, Mater. Sci. Eng. A 705, 402 (2017)

[4] H. Tang, Q. Wang, C. Lei, K. Wang, B. Ye, H. Jiang, W. Ding, Acta Metall. Sin. (Engl. Lett.) 32, 1549 (2019)

[5] J.R. Davis, Aluminum and Aluminum Alloys (ASM International, Cleveland, 1993)

[6] J. Shin, T. Kim, D. Kim, D. Kim, K. Kim, J. Alloys Compd. 698, 577 (2017)

[7] D.G. Eskin, L.K. Suyitno, Prog. Mater Sci. 49, 629 (2004)

[8] Y. Liu, D. Jiang, W. Xie, J. Hu, B. Ma, Mater. Charact. 93, 173 (2014)

[9] Z. Wang, H. Li, F. Miao, B. Fang, R. Song, Z. Zheng, Mater. Sci. Eng. A 607, 313 (2014)

[10] Y. Han, A.M. Samuel, H.W. Doty, S. Valtierra, F.H. Samuel, Mater. Des. 58, 426 (2014)

[11] X. Fan, D. Jiang, Q. Meng, L. Zhong, Mater. Lett. 60, 1475 (2006)

[12] C. Mondal, A.K. Mukhopadhyay, Mater. Sci. Eng. A 391, 367 (2005)

[13] D. Xu, Z. Li, G. Wang, X. Li, X. Lv, Y. Zhang, Y. Fan, B. Xiong, Mater. Charact. 131, 285 (2017)

[14] B. Li, Q. Pan, C. Chen, H. Wu, Z. Yin, J. Alloys Compd. 664, 553 (2016)

[15] G.S. Peng, K.H. Chen, S.Y. Chen, H.C. Fang, Mater. Sci. Eng. A 641, 237 (2015)

[16] M. Amne Elahi, S.G. Shabestari, Trans. Nonferrous Met. Soc. China 26, 956 (2016)

[17] Y.M. Peng, H. Huang, Y. Wang, H.M. Li, Z.R. Nie, P.P. Zhang, Sci. Technol. Eng. 11, 1671 (2011)

[18] P. Jia, Y. Cao, Y. Geng, L. He, N. Xiao, J. Cui, Mater. Sci. Eng. A 612, 335 (2014)

[19] X. Lv, E. Guo, Z. Li, G. Wang, Rare Met. 30, 664 (2011)

[20] X. Yuan, D. Yin, X. Yu, K. Pan, S. Lu, T. Hu, Z. Lv, Z. Zhu, Chin. J. Nonferrous Metal. 27, 459 (2017)

[21] D.K. Xu, P.A. Rometsch, N. Birbilis, Mater. Sci. Eng. A 534, 244 (2012)

[22] Y. Shi, Q. Pan, M. Li, Z. Liu, Z. Huang, Trans. Nonferrous Met. Soc. China 25, 3560 (2015)

[23] L. Hai, C. Dahu, W. Zhixiu, Z. Ziqiao, J. Mater. Sci. 43, 1583 (2008)

[24] C. Hua, Y.G. Zhang, X.W. Li, B.H. Zhu, F. Wang, B.Q. Xiong, Chin. J. Rare Met. 32, 803 (2008)

[25] Y. Xiao, Q. Pan, W. Li, X. Liu, Y. He, Chin. J. Mater. Sci. Eng. 28, 919 (2010)

[26] H. Wu, S. Wen, J. Lu, Z. Mi, X. Zeng, H. Huang, Z. Nie, Trans. Nonferrous Met. Soc. China 27, 1476 (2017)

[27] L. He, X. Li, P. Zhu, Y. Cao, Y. Guo, J. Cui, Mater. Charact. 71 , $19(2012)$

[28] K. Ma, H. Wen, T. Hu, T.D. Topping, D. Isheim, D.N. Seidman, E.J. Lavernia, J.M. Schoenung, Acta Mater. 62, 141 (2014)

[29] X.Y. Liu, Q.L. Pan, Z.L. Lu, S.F. Cao, Y.B. He, W.B. Li, Mater. Des. 31, 4392 (2010) 